Conference Paper

\title{
K-Pop's popularity strategy in the international arena
}

\author{
Ayu Nur Aini*, Muhammad Fahmi, Andri Ardhiyansyah, Bagja Rahma Putra
}

Nusa Putra University, West Java, Indonesia

*Corresponding author:

E-mail:

ayu.nur_mn19@nusaputra.ac.id

\begin{abstract}
This study aims to identify the successful strategy of K-pop music so that it can enter the global market from talent search to marketing. This study uses the literature review method, in this study we find that the success of the K-pop industry is the result of the strategy. such as in developing the talent of a girl band or boyband candidate using the "idol farm system" system, then using offline and online promotions. besides that the agency implemented and learned about the 4.0 marketing system. by seeking segmentation, performs 5 stages of methods of bringing in consumers, namely being aware, interested (appeal), seeking (ask), taking action (act), and supporting (advocate). Apart from the 5 approaches, there are 4 stages in marketing music, namely introducing 4.0 consumers, then doing human-oriented marketing, then doing online and offline marketing, and engagement marketing for brand affinity. To enter the international market, K-pop already has many advantages because it already has its genres and characteristics, in K-pop music also contains modernized traditional elements.
\end{abstract}

Keywords: Music industry, marketing strategy, market segmentation, K-pop, Promotion, Value chain.

\section{Introduction}

The music industry is an industry in which music compositions, records, and performances are sold. Among the many people and organizations operating in this industry are musicians who transform and perform their music; companies and professionals who make and sell recorded music (The Economist. 2008). In the music industry, many types of music are traded, one of which is pop music, according to Storey (1999). Marketing strategy is an analysis of strategies to develop and carry out marketing activities in the selection of product targets. The determination of marketing and development goals is aimed at helping implementation and management to determine the share that can fulfill consumer desires. With so many competitors the company needs an effective strategy so that the music that is produced can be accepted and liked by people so that every music that is produced can get more attention from people.

$\mathrm{K}$-Pop is a type of music that carries the dance-pop genre or is defined as pop music combined with charming faces and dancing skills coupled with song lyrics in Korean combined with western in certain parts (Nastiti, 2010). Where the music is a combination of western pop music with its distinctive music, which ultimately becomes a unique rhythm. Several genres are included in the music, such as the traditional South Korean genre itself to hip hop (rap) and electronic dance music (EDM). Apart from genres that contain unique rhythms, there are also many South Korean or K-pop artists who have the characteristics of idol culture; namely the formation of many boy bands and girl groups which in every boyband and girl group that we form will be presented with group dances that are formed.

The synchronization is unique and has the characteristics of each band; Not only that, from the lyrics of the song, K-Pop uses mixed lyrics, namely English with the original Korean language. Simultaneously, the word 'K-Pop' itself refers to the music, the music made by South Korea in general and as a 
whole. The meaning of k-pop itself refers to South Korean pop music as music made by South Koreans for non-Koreans (Messerlin \& Shin, 2013).

As we all know that currently, the k-pop music industry has entered the global scene. In fact, in recent years, K-pop music has been able to compete with western music for example, such as the Gangnam style song sung by PSY, this can be seen in terms of realistic achievements starting from entering the billboard, too many western singers. who want to collaborate with them such as Selena Gomez, Cardi B, Halsey, Nicki Minaj, Dua Lipa, Brothers Jones, Justin Bieber, and many more. What's more, they want to collaborate with k-pop artists or idols like Blackpink, BTS, Exo, Red Velvet, PSY.

Also, their music is well received by almost all global communities, from teenagers to adults. Therefore, the emergence of K-Pop in the global market needs to be further understood and analyzed in terms of the marketing strategy behind the international popularity of K-Pop music, then the strategies and methods used by these K-pop companies or agencies can be imitated and applied so that the quality of Indonesian music the better.

Suppose we see the rapid development of k-pop music today in the international and global arena. So, we want to find out more about the strategies used by the k-pop music industry itself in marketing its music both online and offline because by entering the industrial era 4.0 companies or agencies must be able to adapt to the current market, as well as the strategies they take to be able to exist. at the current stage which we will discuss in this journal.

By writing this journal, the writer hopes that this journal can help readers to find out about marketing strategies, producing, and shaping music and can make better use of digital platforms to make them more useful.

\section{Literature Review}

To be able to answer the research questions appropriately, it is necessary to understand the research theme from its theoretical studies. Therefore, this research used the approach of community development theory due to the study on human resources capacity building is included. Several references show that the concept of community development is the development of locality-based community initiatives through comprehensive activities that can be categorized into several fields affecting each other and becoming correlated. Thus, the target is not only about human capacity building but also about the broader system. "Economic development is part of community development, which seeks to build all five community capitals, not only enhancing the community's economy but its environment, social structures, attitudes, and assets."

The formulates activity fields in community development programs into human development, business development, institutional development, and environmental development. Further explanation is as follows: (1) Human Development is the main activity because it is not only about becoming a beneficiary, human being (human resource) is the essential requirement determining the success of development being done. Human development activities are: (a) individual building capacity, such as personal capacity including characters and professional development; (b) technical skill capacity building. (2) Business Development refers to the formation of business activities as an attraction and a media to maintain sustainable development activities. (3) Environmental Development is required to maintain the environment from physical, social, and cultural environmental damages that can disturb the sustainability of the program and the life of the targeted community. However, also, to prevent the damages, the scope of community development activities leads to the users of the physical environment to fulfill the needs of business raw materials and conditions of the socio-cultural environment supporting and creating sustainable community development. (4) Institutional Development is required to solve the problem and support the sustainability of human development, environmental development, and business development activities. Resource development for SMEs in industrial centers is an activity that can be conditioned naturally, in addition to engineering activities carried out by local institutions, the form of activities in the form of increasing skills, understanding business problems, and developing entrepreneurial motivation. 
Referring to Mardikanto's statement above, the research scope in this article is related to workshop owners' resources development on both wooden batik centers. Meanwhile, according to professional character formation for entrepreneurs through the formation of an entrepreneurial mindset and technical business skills such as marketing, finance, production, and human resources. The entrepreneurial mindset is a creative thinking pattern in dealing with all business problems through an introduction of creative thinking strategies and empowerment actions. Also, it invites and encourages entrepreneurs to get used to doing it in their daily lives so that the mindset will form automatically. Owning an entrepreneurial mindset is very helpful for SMEs in increasing business capacity, this is driven by the courage to take risks by creating product innovations or management functions in solving business problems. A study about a strong relationship between the willingness to take risks (risk tolerance) and entrepreneurial business success, which further stresses the need for including risk in entrepreneurship education and training programs.

\section{Industry}

According to (Arsyad, 2004) in economic terms, the industry has two definitions, name-ly:

1. the industry is an association of similar companies; for example, the paper industry means the association of paper-producing companies.

2. The industry is an economic sector in which productive activities process raw goods into semi-finished or finished goods.

Apart from industries such as market companies, there are also creative industries were in the creative industry, a collection of companies running in the art sector. According to Simatupang (2007), the creative industry is an industry that relies on skills, talents, and elements of creativity that have the potential to increase welfare. Besides, the Ministry of Trade of the Republic of Indonesia in 2009 also said that "The creative industry is an industry that comes from the use of skills, creativity, and talents possessed by individuals in creating welfare and employment opportunities. This industry will focus on empowering the creativity and creativity of an individual.

\section{Characteristics of the creative industry}

The creative industry has the following characteristics:

1. The main elements are creativity, expertise, and talents that can increase welfare through the offering of intellectual creations.

2. Based on ideas or ideas.

3. The resulting product is a creative product with a short life cycle, high risk, high margin, high diversity, high competition, and easy to imitate.

4. Providing creative products directly to customers and supporting creative value creation in other sectors that are indirectly related to customers.

5. Good cooperation and collaboration between various parties who play a role in the creative industry are needed, such as intellectuals, the business world, and the government.

6. The creative industry can be developed widely and is not limited to various business fields. The concept that is built is relative.

\section{Market segmentation}

Market segmentation is an activity in which a company groups its consumers according to age, social strata, etc. According to Kotler and Armstrong (2008), the notion of marketing strategy is marketing logic. The business unit hopes to create value and benefit from its relationship with consumers.

For the segmentation process to be carried out properly, there are at least four criteria that must be met so that everything goes according to plan, can be done effectively, and is beneficial to the company, namely: 
1. Measurable, which means that market segmentation can be measured to a certain degree. All data that includes research, analysis, and other data can be proven with measurable data so that companies can determine segments precisely and accurately.

2. A substantial (substantial) segmentation process must be able to provide benefits for the company.

3. Actionable (can be followed up) a good segmentation process can be realized using a plan that has been made by the company.

4. Accessible means that every consumer can easily access any information in the company.

Apart from the four criteria above, segmentation is also grouped into 3, namely:

1. Geographical Segmentation Consumers are differentiated based on demographic characteristics, such as age, gender, education, occupation, and so on.

2. Demographic Segmentation

Consumers are differentiated based on residence, for example, the region within a country (West Indonesia East Indonesia), islands, provinces, cities, cities/towns/villages.

3. Geodemographic Segmentation Consumers living in a certain geographic area are believed to have similar demographic characteristics (but the geographic area should be as narrow as possible, for example.

\section{Value chain}

The value chain is a collection associated with value creation activities, starting with basic raw materials, coming from suppliers, and moving to a series of value-added activities, including the production and marketing of products, in the form of goods or services. It ends with distribution for product acceptance by end consumers (Assauri, 2011), A value chain is not only about 'supply' like a supply chain, but also about 'demand.' Because it is a 'demand impulse' that triggers value-added activities and processes.

Value chains are divided into two categories of activity; (1) primary (primary activity) which consists of logistical activities in, operations, outbound logistics, marketing \& sales, and services, and (2) support activities, which consist of general administration, human resource management, research \& development, and procurement (Pearce, 2008).

\section{Material and Methods}

The method used in this study is to use the literature review method. Namely, the search for international and local literature carried out through Scopus, the journals we chose were seen from how complete the material was and how broad the material was about K-pop, strategy, and marketing. In the early stages of searching for journal articles, 247 articles were obtained using the keywords "K-pop," Hallyu, "Music Industry," K-pop Music. "Of these, only six journal articles were included in the criteria according to the study. Then from the seven journals obtained according to the criteria we have determined, namely:

1. Complete journal identity.

2. There is a material that is needed

3. to be easily understood

4. using the literature review method or not using methods related to calculation.

Five journals of medium quality and two journals of low quality because the 2 journals still fall into the journal criteria we need, even though not all data are complete. After the mention of the various journals that have been obtained, the researcher makes conclusions which are the results of the research. 


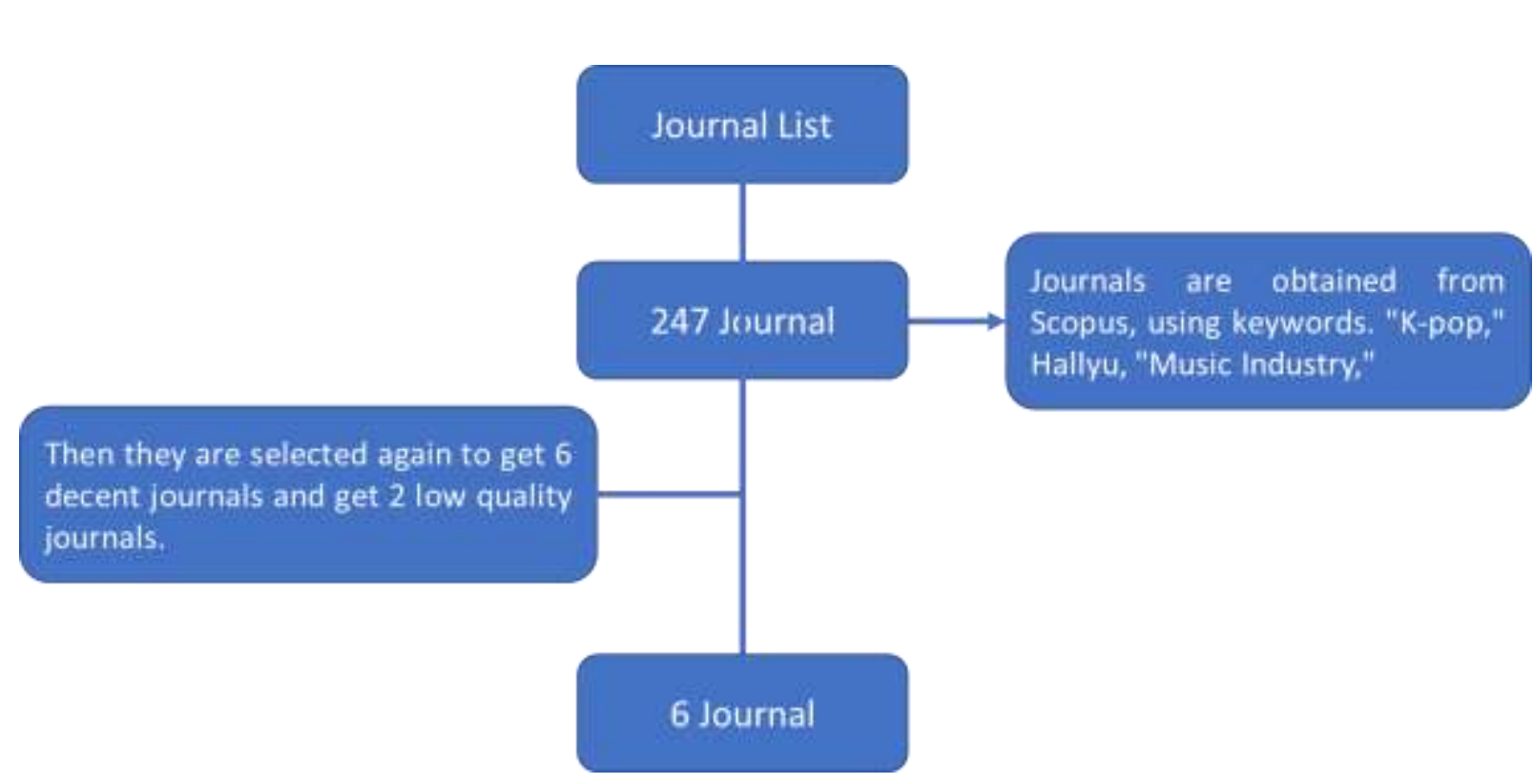

Figure 1. The scheme of the research results

\section{Results and Discussion}

In creating its idols, K-pop agencies have implemented different management strategies from other or other countries, namely implementing a value creation strategy from K-pop through several processes called the word "Idol Farm System" put forward by Professor Lee Dong- Yeon.

This system is done by recruiting agencies by auditioning and recruiting talents that are considered promising from an early age, starting from the age of 9-11 years. After recruitment, they are trained seriously for several years, depending on the candidates' quality. In training itself, they are trained in language, vocals, and dancing. They are placed in a dormitory place (Messerlin \& Shin, 2013), applied to all aspiring idols before they finally debut as an idol group, soloist, or duo. This system was previously implemented by only one agency, namely a large agency in South Korea, namely SM Entertainment, which eventually all agencies in South Korea implemented the system.

Informing idol candidates, K-Pop formed a system called the "Idol Farm System," where this system starts with an audition process, training, forming groups consisting of several people until they finally debut their idols. To reach the targeted market, K-Pop entertainment agencies also select audition participants recruited with various criteria. In addition to having talent in singing and dancing, several agencies also pay attention to participants in terms of physical aspects, namely the face and body posture's visual appeal to attract fans, both local fans. And global.

Then to achieve the targets that have been planned, the K-pop music industry will promote their debuted idols using two channels, namely online and offline. For offline promotions, they usually do live stages on national $\mathrm{TV}$, hold showcases or mini-concerts. In contrast, their online promotions use social media that are currently trending, such as promotions via Youtube, Instagram, and Vlive. Online promotions usually present teasers with various concepts in the album via pictures or short video tweets.

In the distribution and marketing process, at first, it was only done manually or traditionally, namely idols promoting through appearances on various music shows on National TV and also selling physical albums. However, along with technological developments that have been sophisticated so far, the K-pop music industry has finally developed marketing through digital marketing and content marketing through social media, which is currently used by teenagers such as Instagram, YouTube, Tik Tok and marketing through streaming platforms such as Twitch, YouTube. Live, Instagram Live.

Then in the K-pop music industry apply the 4.0 market system. Agencies in the K-pop music industry approach and familiarize themselves with digital consumers who are their target. Where at this time, 
the most influential in the digital era is the digital consumers. This is because digital consumers are trendsetters, social connectors, and brand speakers or mediated by almost all brands.

After going through introducing them to market 4.0, they do marketing oriented towards a brand appeal. They enter every criterion attribute into music, and idols will debut physical, intellectual, social mobility, emotional, personality, and morality. In this case, they enter emotionally into the music they create, such as inserting emotions that follow the problems being experienced by the listener or situations and conditions that suit the listener. It will be effective to make fans interested in listening and feel the problems they feel have subsided effectively and can provide hope.

Then K-pop itself uses Omni channels to form commitments efficiently and effectively. They combine their previous experiences with traditional and digital media. They are also using current technological sophistication to increase their idols' popularity, namely using applications on mobile phones and social media.

K-pop as a global project and product seems to be facilitated by the national desire to globalize national cultural content and expand the cultural industry. Even though the content is considered hybrid pop music, the Korean wave has become a soft power instrument for South Korea with a source in the form of culture, namely popular culture (pop culture), which is mass-produced for the public consumption of other countries. The Korean wave is used to achieve the goal of gaining economic benefits for South Korea. Economic benefits for South Korea are achieved not only by obtaining profits from the export of cultural products but also through the use of the Korean wave's popularity in other countries as an attraction and promotion tool in marketing other economic value products such as tourism and commercial products.

From the six research journals described, it can be concluded that K-pop's successful strategy to enter the international market comes from internal factors in the k-pop music industry itself, namely in the recruitment and debuting system they do. The journal (Diari \& Mahyuni, 2019) states that this research supports the theory used, namely the marketing strategy 4.0. Which is the implementation of marketing strategies that need to be adjusted to the times to survive and excel in facing competition. The research contributes to a practical understanding of how to apply value chain analysis to identify the competitive advantage of a company through activities that give value differences to produce results.

The suggests that future studies of K-pop might seek to analyze how fan life, authenticity, and emotional investment shape the way Koreans live in the West (such as Korean-Americans), Korean culture, and Korea itself is negotiated in terms of changing ideas about gender, race, and culture in the West. It can also help us understand the growing popularity of K-pop in such a diverse fan base; with many fans of varying gender, age, and ethnic/racial diversity interested in K-pop. This study provides new empirical data on how the emotional investment of K-pop fans, who are distant from Korea itself, learn, support, and connect with Korean culture.

$\mathrm{K}$-pop is a product that is influenced by the forces of globalization and nationalization. The global circulation of K-pop is indebted to the role of the Korean nation-state in branding its cultural products globally. K-pop as a global project and product seems to be facilitated by the national desire to globalize national cultural content and expand the cultural industry. Even though the content is considered hybrid pop music, K-pop has become a Korean product that 'K' cannot avoid.

From the journal, the Korean wave has become an instrument of soft power for South Korea with a source in the form of culture, namely popular culture (pop culture), which is mass-produced for public consumption in other countries. The Korean wave is used to achieve the goal of gaining economic benefits for South Korea. Economic benefits for South Korea are achieved not only by obtaining profits from the export of cultural products but also through the use of the Korean wave's popularity in other countries as an attraction and promotion tool in marketing other economic value products such as tourism and commercial products. South Korea's strategy in using the Korean wave to gain economic benefits can be copied by Indonesia. This strategy is one of the alternatives related to optimizing the role of culture in the country's economy. The success of South Korea in promoting its culture not only has a positive impact on the nation's cultural identity but also the country's economy. Culture, especially popular culture, is rarely involved when we discuss the country's economy. 
Since the mid-1990s, in the development of the South Korean music industry, entertain-ment agencies' role is very important and needed in the South Korean music industry compared to record labels or specialized music companies (Negus, 2015). In the early history of k-pop music before entering the European music scene, entering the billboard and the American music industry, K-pop has started its international career in China. The South Korean group that debuted for the first time and was introduced globally in China was NRG (New Radiancy Group), with its unique characteristics. A diverse music genre that was easily favored by young people was able to bring success to the Chinese music industry.

Apart from the genres and characteristics that k-pop itself has, one thing that makes people like kpop is its sales technique. At one point, a boy/girl band will release an album. They don't only sell CDs with songs, but they also sell supporting products such as photo cards, photo albums, posters, etc.

For the Korean state itself, K-pop is one of the tools that can improve the country's economy; therefore, the government provides financial support for the K-pop promotion itself. As we know, nowadays, $\mathrm{K}$-pop music sells quantity and sells quality, so many people are starting to like k-pop.

\section{Marketing strategy}

Promotion is one of the variables in the marketing mix that is very important for companies to implement in marketing service products (Rambat \& Hamdani, 2006). Promotion is carried out to inform, remind, and persuade the brand or product that is made can be known, remembered, or become the top of people's minds and purchased by consumers.

According to Kasmir (2004), there are several ways or means of promotion, namely:

1. Advertising (Advertising).

2. Publicity (Publicity).

3. Personal Selling.

4. Sales promotion (Sales Promotion).

According to Kotler (2012) is a marketing logic in which the company hopes to create value for customers and achieve profitable relationships with customers. A marketing strategy is a plan that describes the company's expectations of the impact of various marketing activities or programs on demand for its product or product line in a particular target market. Companies can use two or more marketing programs simultaneously because each type of advertising, sales promotion, personal selling, customer service, or product development has a different effect on demand. Therefore, a mechanism is needed to coordinate marketing programs so that they are aligned and synergistically integrated. This mechanism is known as a marketing strategy. Generally, the best marketing opportunities are obtained from efforts to expand primary demand, while the best growth opportunities come from efforts to expand selective demand.

Marketing 4.0 is marketing oriented towards the natural change of customer paths in the digital economy, combining online and offline interactions between companies and customers, blending style with substance in building brands and finally completing machine-to-machine connectivity with a human-to-human touch. Human beings to strengthen customer engagement in a digital era like this, young people are the main segmentation and as the most influential consumers because today young people are very active in surfing the internet.

There are five stages to make consumers become loyal customers; namely, customers must be aware of the product (aware), then recognize the product (appeal), seek more information about the product (ask), after the customer knows all information about the product, the customer has the potential to buy the product (act), and the last stage the customer will suggest the product to new customers.

\section{K-Pop music industry value chain, K-pop Agency}

The K-pop music industry is the same genre as Pop in other countries. Still, in presenting its music to the public, it is different from Pop that we always hear from other pop music industries such as I-Pop, 
Western, Western Pop Music. The K-Pop agency took the opportunity to direct its music and introduce its music globally with a musical appearance coupled with high-intensity choreography in the mid1980s, at which time disco music and Michael Jackson had retired and disappeared world of entertainment (Messerlin \& Shin, 2013). From here, the K-pop Agency began to make a change strategy in company management, starting from a large Korean agency, namely SM Entertainment, which made the "Idol Farm system" system, which is to make stages for aspiring idols that they will introduce to the public or debut. This system process begins with the audition process after the participants feel that they have promising talents for their agency. Idol candidates will enter the training stage; they will usually be given maximum training to maximize the talents that aspiring idols have, such as language training and vocal pull dance. For them to have closeness with other idol candidates named in a group, they usually place them (idol candidates) in the same place, namely the dormitory. After this stage and having entered into the formation of a group, the agency will debut them according to the concept drawn up since pre-debut.

When viewed from the standard process carried out by the K-pop music agency to achieve its target, it can be seen that this process forms a pattern of value chain models created by Michael Porter from Harvard, which is the primary activity of the value chain consisting of Lutfia (2012) a). into this business (recruiting talent that they feel is promising), b). changing the items that will later become the final product (preparation called training), c) sending the final product (debuting the prepared idol), d). sales or marketing (Promotion conducted by the agency against idols due to it), 5). Production service (service to fans provided by the agency).

In the fourth stage of the K-pop value chain, they communicate or promote their debuted idols by empowering physical album sales, advertising, and communication tools such as social media and streaming platforms. In stage five, namely CRM, they create events that can make fans satisfied, namely by having fan meetings, fan signs, and concerts, where this is done so that there is a comfortable and familiar atmosphere between fans and their idols.

\section{Application of marketing 4.0 in the K-pop music industry}

In the K-pop music industry, they use marketing 4.0 as a tool to distribute their music. Besides, they also carried out several stages to know and recognize consumers, 4.0 Young people, women, and citizens are the most influential consumer segments in the digital era.

Consumers 4.0 go through five stages of the journey (customer path $5 \mathrm{~A}$ ) to become loyal customers, namely; the stage of being aware of the brand (aware), the stage of being interested in recognizing the brand (appeal), the stage of actively seeking information about the brand (ask), the stage of consumption/purchase (act), and the stage of advocating brands to new consumers (advocate) (Diari \& Mahyuni, 2019).

In the implementation of marketing 4.0, the K-pop music industry carries out each phase well in its strategy, as well as the stages taken by the K-pop music industry in communicating its music to global publishing:

1. In the initial stage, they first introduced and approached consumer 4.0 (digital consumers),

2. The second stage of K-Pop does human-oriented marketing for brand appeal. This is done by creating a brand that fulfills six human attributes: physical, intellectual, sociability, emotional, personality, and morality. At this stage, they tend to set beauty standards such as a slim body and pure white skin. Which will attract and be able to attract the attention of global and local consumers. Besides, in terms of music, they produce songs with life themes, such as social problems, love, and life's dilemmas, so that consumers or listeners indirectly feel they have similar problems and are finally interested in listening. What is more interesting is that it makes listeners empathically want to listen to music because it has the same story as what is felt.

3. In K-pop music itself, they present music in a different form. Usually, in one idol group, they form units such as playing vocals, playing rappers, and playing dancers, making K-pop music look more diverse and unique. Consumers will not be bored listening and see because there are 
many musical elements in it. Just singing but also dancing and rap, which makes k-pop music even more interesting.

4. Content marketing for brand curiosity, which includes the process of creating, selecting, sharing, and enlarging content that is attractive, relevant, and useful for a clear audience to create conversations about related content.

5. Omni-channel marketing for brand commitment. Blends experience, traditional and digital media. In carrying out K-pop promotions using offline and online channels to communicate or promote their idols who will either debut or come back. Usually, they will promote offline through showcases or mini-concerts at national TV stations and use online channels for global promotions such as social media currently trending, namely Instagram, Twitter, Youtube, and others. In this promotion, they usually also sell physical albums that are different from albums made by other music industries. In the album they make, they will include a few knick-knacks such as photo cards, photo albums that are packaged like magazines,

6. Engagement marketing for brand affinity. They have enhanced consumer experience by leveraging mobile applications, social CRM, and gamification. In this stage, they provide the best service for fans to use to feel closer to their idols. In this case, K-pop usually provides space for idols and fans through applications such as Vlive, Bubble

\section{Conclusion}

From the six research journals described, it can be concluded that K-pop's successful strategy to enter the international market comes from internal factors in the k-pop music industry itself, namely in the recruitment and debuting system they do. In the process, K-pop matures the quality of aspiring idols so that when the debut of local and global consumers can see from the quality of their idols without any product defects. The standard strategy for maturing the aspiring idol is using the "idol farm" system. This system begins with recruitment and training until finally being debuted as an idol group, soloist, and duo.

In finalizing aspiring idols, K-pop will also provide maximum training with quality facilities such as language, vocal, and dance training. Then the K-pop music industry also implemented the market 4.0 system well and dared to take risks. In the implementation of market 4.0, the K-pop music industry implements it according to the stages of the strategy in the digital era to quickly reach the global market. In the process, K-pop Music communicates or promotes its music with two online and offline channels. In online promotions, they usually do it through social media or streaming platforms such as Instagram, Twitter, Youtube, Twitch. In contrast, offline promotions are carried out through showcases or miniconcerts and on national TV stations.

Apart from the internal Kpop strategy itself, what makes K-pop able to achieve popularity as it is today is the desire of the country or the government itself. K-pop as a global project and product is facilitated by the national desire to globalize national cultural content and expand the cultural industry

\section{Acknowledgment}

We as writers would like to thank Andri Ardhiyansyah, MBA as the supervisor for our research assistance.

\section{References}

Arsyad, L. (2004). Ekonomi pembangunan. Edisi Keempat. Yogyakarta: STIE YKPN.

Assauri, S. (2011). Strategic management, sustainable competitive advantage. Indonesia: Jakarta press.

Departemen Perdagangan Republik Indonesia. (2009). Pengembangan ekonomi kreatif Indonesia 2025. Jakarta : Departemen Perdagangan Republik Indonesia

Departemen Perdagangan Republik Indonesia. 2008. Pengembangan Industri Kreatif Menuju Visi Ekonomi, Kreatif Indonesia 2025, Jakarta:

Departemen Perdagangan Republik Indonesia. 
Diari, N. K., \& Mahyuni, L P. (2019). Strategi sukses K-Pop memasuki pasar musik mainstream: Bighit Entertainment, BTS, dan 'Army. 16(3), $31-47$.

Kasmir. (2004). Pemasaran Bank. Jakarta: Prenada Media.

Kotler. K. (2012). Manajemen pemasaran. Edisi 12. Jakarta: Erlangga

Kotler, P., Armstrong, G, (2008). Prinsip-prinsip pemasaran. Erlangga, Jakarta.

Lutfia, A. (2012). Analisa Pengaruh Value Chain Terhadap Persaingan Dalam Mencapai Kepuasan Pelanggan Pada Perusahaan Precast Di Indonesia. Jakarta: Jakarta press

Messerlin, P.A., \& Shin, W. (2013). The K-pop Wave: An Economic Analysis. (Jurnal elektronik). Diunduh dari https://papers.ssrn.com/sol3/papers.cfm?abstract_id=2294712.

Nastiti, A. D. (2010). Korean Wave Di Indonesia: Antara Budaya Pop, Internet, dan Fanatisme Pada Remaja. Journal of Communication, 1(1), $1-23$.

Negus, K. (2015). The South Korean music industry: A Literature Review. CREATe Working Paper Series. Economic Analysis, 1(13), 22-29

Pearce, R, (2008). Manajemen strategi (formulasi, implementasi, dan pengendalian). Jakarta: Penerbit Salemba Empat.

Rambat, L., Hamdani A. (2006), Manajemen Pemasaran Jasa, Jakarta: Salemba Empat.

Simatupang, T. (2007). Ekonomi kreatif menuju era kompetisi dan persaingan usaha ekonomi gelombang IV. Bandung: Institut Teknologi Bandung.

Storey, J. (2006). Cultural studi es dan kajian budaya Pop. Yogyakarta: Jalasutra Fandy Tjiptono. 